\title{
Olbrzymia torbiel śledziony - opis przypadku
}

\section{Giant splenic cyst: a case report}

\author{
Andrzej Żyluk $\bowtie$, Piotr Puchalski \\ Pomorski Uniwersytet Medyczny w Szczecinie, Klinika Chirurgii Ogólnej i Chirurgii Ręki, ul. Unii Lubelskiej 1, 71-252 Szczecin \\ $\triangle$ azyluk@hotmail.com
}

\section{ABSTRACT}

The case of a giant, nonparasitic splenic cyst, accidentally diagnosed in a young woman, is reported. The cyst was poorly-symptomatic, with only a discrete change of abdominal contour. The diagnosis was confirmed by USG and abdominal computed tomography

\section{ABSTRAKT}

Przedstawiono przypadek olbrzymiej, niepasożytniczej torbieli śledziony, manifestującej się bardzo dyskretnymi objawami (zmianą obrysu brzucha), którą wykryto przypadkowo u młodej kobiety. Rozpoznanie ustalono na podstawie badania ultrasonograficznego i tomografii komputerowej jamy brzusznej. scanning. The patient was operated on, and the cyst, containing $2.5 \mathrm{~L}$ of serosal fluid, was successfully excised, sparing almost the whole spleen. The postoperative course was uneventful, and histological examination showed the epidermoid character of the cyst. Keywords: splenic cyst; operative treatment; sparing surgery.

Pacjentkę operowano, a torbiel zawierającą 2,5 L płynu surowiczego udało się wyciąć z zaoszczędzeniem niemal całej śledziony. Przebieg pooperacyjny był niepowikłany, badanie histopatologiczne wykazało epidermoidalny charakter torbieli.

Słowa kluczowe: torbiel śledziony; leczenie operacyjne; leczenie oszczędzające.

\section{WSTEP}

Torbiele śledziony należą do stosunkowo rzadkich patologii. Zasadniczo dzieli się je na pasożytnicze i niepasożytnicze. Torbiele pasożytnicze najczęściej spowodowane są zakażeniem tasiemcem bąblowcem (Echinococcus granulosus), przedostaniem się larw pasożyta do krwiobiegu i ich zasiedleniem w narządach wewnętrznych, w tym w śledzionie. Torbiele niepasożytnicze dzieli się na pierwotne i wtórne. Pierwotne są zmianami wrodzonymi o typie dermoidalnym, epidermoidalnym lub endodermoidalnym. Torbiele wtórne najczęściej są pourazowe i rozwijają się po śródmiąższowych lub podtorebkowych pęknięciach śledziony, a znacznie rzadziej powstają w przebiegu niektórych chorób, np. mononukleozy zakaźnej, gruźlicy lub malarii [1,2,3]. Większość niewielkich i średnich torbieli śledziony nie daje żadnych objawów klinicznych i jest wykrywana przypadkowo podczas wykonywania badania USG jamy brzusznej w ramach diagnostyki innych chorób lub w trakcie sekcji zwłok [4, 5]. Objawowe torbiele mają zwykle znaczne rozmiary, a powodowane przez nie dolegliwości są nieswoiste i nieuciążliwe, np. asymetryczne powiększenie obrysu brzucha, wyczuwalny opór w lewym podżebrzu i pobolewania brzucha w tej okolicy.

W pracy przedstawiono przypadek młodej pacjentki z przypadkowo wykrytą olbrzymią torbielą śledziony o nieustalonej etiologii, którą skutecznie wycięto z zaoszczędzeniem narządu.

\section{OPIS PRZYPADKU}

24-letnia kobieta, studentka stomatologii, zauważyła asymetrię obrysu brzucha z uwypukleniem w lewym podżebrzu. Nie odczuwała żadnych dolegliwości, nie schudła, miała dobry apetyt i uczęszczała normalnie na zajęcia na uczelni. W trakcie ćwiczeń z chorób wewnętrznych poprosiła, aby wykonano jej badanie ultrasonograficzne (USG) jamy brzusznej z powodu zauważonej zmiany obrysu brzucha. Badanie ujawniło olbrzymią torbiel wychodzącą ze śledziony. Rozpoznanie potwierdzono tomografią komputerową jamy brzusznej (ryc. 1). W obrazach TK torbiel była jednokomorowa, wypełniała całe lewe nad- i śródbrzusze, spychając śledzionę do tyłu, a lewą nerkę do dołu (ryc. 1). Badanie nie wykazało obecności innych torbieli ani innych zmian patologicznych w jamie brzusznej. W badaniu klinicznym guz był wyczuwalny ok. $10 \mathrm{~cm}$ poniżej lewego łuku żebrowego i sięgał do linii pośrodkowej brzucha (ryc. 2).

Chorą przyjęto do kliniki autorów pracy z zamiarem wykonania przezskórnej ewakuacji zawartości torbieli pod kontrolą USG, jednak po konsultacji z radiologiem odstąpiono od tego pomysłu ze względu na przeciwwskazania. Z powodu dużych rozmiarów i ryzyka pęknięcia torbieli nie wykonano wcześniej badania w kierunku ewentualnego zakażenia bąblowcem, ponieważ czas oczekiwania na wynik testu krwi wynosi ok. 7 dni. Przypadek skonsultowano ze specjalistą chorób zakaźnych, który na podstawie obrazu radiologicznego i przebiegu klinicznego uznał, że bąblowcowy charakter torbieli jest mało prawdopodobny. Konsultant zasugerował szybkie wykonanie operacji i badanie histopatologiczne wyciętej torbieli. Nie zalecił przeprowadzenia żadnych testów śródoperacyjnych.

Pacjentkę operowano w znieczuleniu ogólnym, cięciem pod lewym łukiem żebrowym otwarto jamę brzuszną, stwierdzając znacznych rozmiarów cienkościenną torbiel wychodząca ze śledziony. Torbiel nakłuto i ewakuowano łącznie 2,5 L płynu 
surowiczego. Następnie uruchomiono śledzionę, przecinając jej więzadła i oddzielono ścianę torbieli od lewej kopuły przepony, z którą była zrośnięta. Po wytoczeniu śledziony nad powłoki brzuszne stwierdzono, że ściana torbieli płynnie przechodzi w miąższ narządu i nie daje się jej z niego wyłuszczyć (ryc. 3 a,b). Wobec takiej sytuacji odcięto nożem elektrycznym torbiel od śledziony, starając się utrzymywać grubość ok. $1 \mathrm{~cm}$ ściany torbieli i miąższu śledziony (ryc. 3 c). W trakcie wycinania koagulowano lub podkłuwano krwawiące naczynia, a po zakończeniu wycinania torbieli skoagulowano jej ścianę wewnętrzną pozostałą na powierzchni śledziony (ryc. 3 d, e).
Sama śledziona miała nieco większe niż przeciętne rozmiary, ale nie stwierdzono w jej obrębie żadnych dodatkowych patologii. „Wnękę” po wyciętej torbieli wypełniono fragmentem sieci większej (ryc. 3 f). Przy operacji nie odnotowano znacznego ubytku krwi. Jamę brzuszną zamknięto szwem warstwowym, pozostawiając dren w okolicy lewego podżebrza. Przebieg pooperacyjny był niepowikłany, chorą wypisano do domu w 4. dobie. Badaniem histopatologicznym ściany torbieli wykazano utkanie łącznotkankowej torbieli częściowo wyścielonej mezotelium. Nie stwierdzono cech zakażenia bąblowcem ani rozrostu nowotworowego.
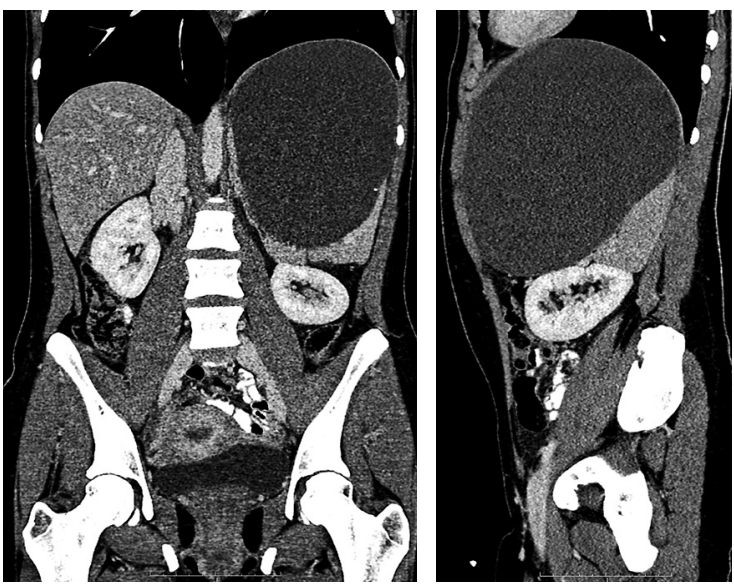

RYCINA 1. Badanie tomograficzne jamy brzusznej z widoczną olbrzymią torbielą śledziony
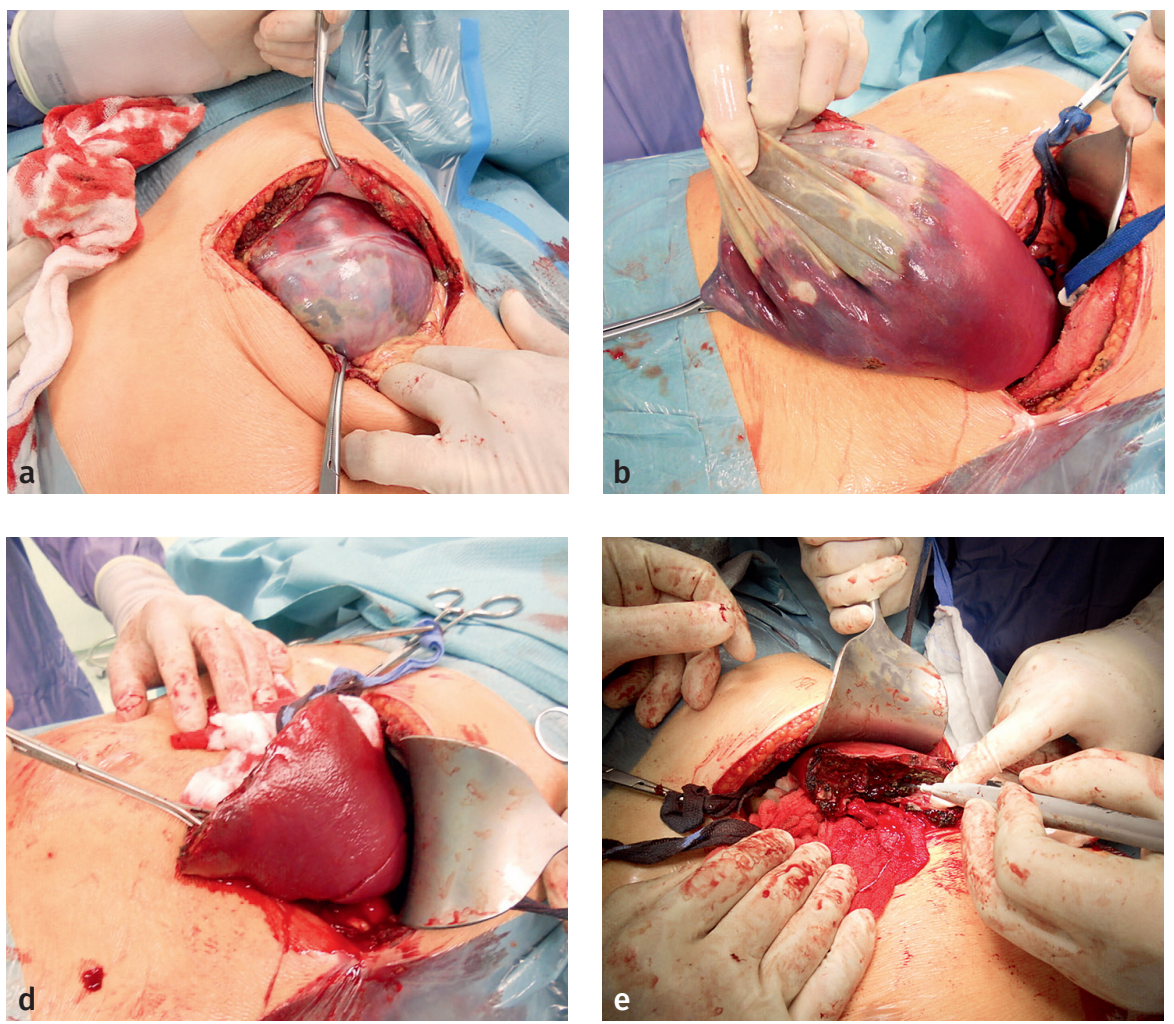

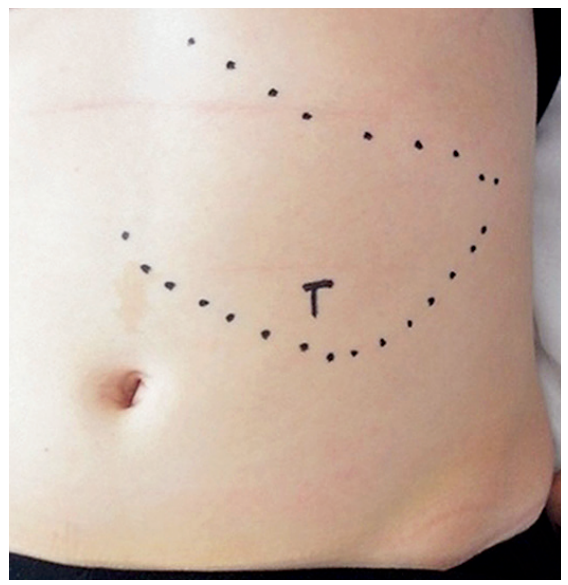

RYCINA 2. Widok brzucha pacjentki zzaznaczonym obrysem wyczuwalnej torbieli śledzony (dolna linia) i tuku żebrowego (górna linia)
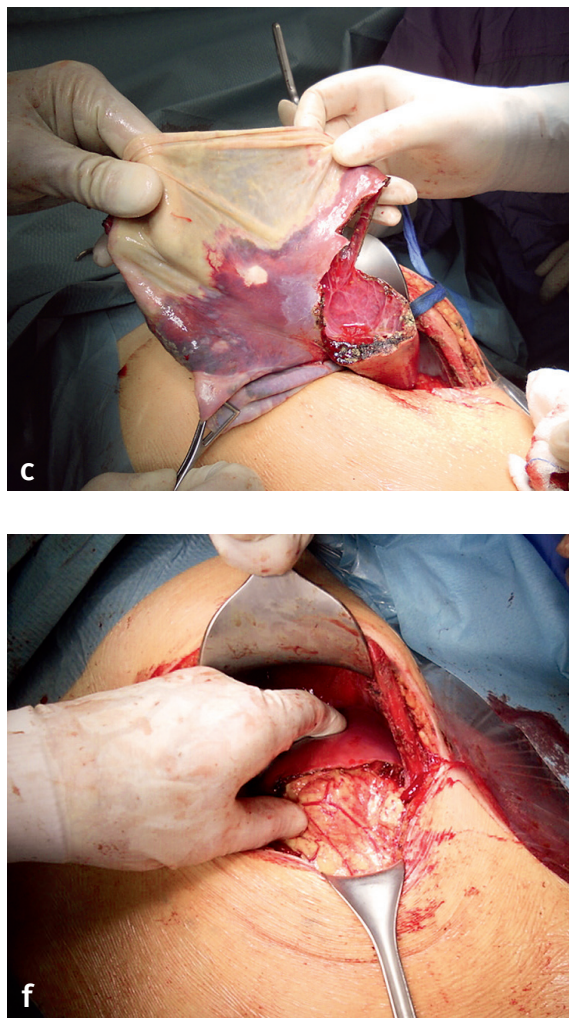

RYCINA 3. Wycięcie olbrzymiej torbieli śledziony: a) widok torbieli po otwarciu jamy brzusznej; b) widok śledziony po jej uruchomieniu z częściowo ewakuowaną zawartością torbieli; c) odcinanie torbieli od miąższy śledziony; d) widok pozostawionej śledziony po odcięciu torbieli; e) koagulacja ściany torbieli przylegającej do śledziony; f) wypełnienie ubytku w miąższu śledziony siecią, przed zamknięciem jamy brzusznej 


\section{DYSKUSJA}

Niepasożytnicze i nieurazowe torbiele śledziony są rzadkie i w piśmiennictwie niewiele można znaleźć publikacji na ich temat. Leczenie torbieli śledziony zależy przede wszystkim od ich rozmiarów. Małe torbiele o średnicy nieprzekraczającej 4-5 cm mogą być leczone zachowawczo i obserwowane. Większe wymagają leczenia operacyjnego, ponieważ grożą pęknięciem, co może spowodować silny ból, krwawienie wewnątrzbrzuszne lub zakażenie. W zakres stosowanych interwencji i technik operacyjnych wchodzą:

- nakłucie i ewakuacja zawartości torbieli w asyście USG,

- częściowe wycięcie torbieli (fenestracja lub marsupializacja),

- całkowite wycięcie torbieli z zaoszczędzeniem śledziony,

- wycięcie torbieli razem ze śledzioną.

Leczenie operacyjne może być wykonane metoda otwartą lub laparoskopową (obecnie znacznie częściej stosowaną).

Z przeglądu piśmiennictwa, które w większości składa się z kazuistyki, wynika, że:

1. Nakłucie przezskórne torbieli jest niechętnie wykonywane ze względu na obawę przed powikłaniami (krwawienie, zakażenie) i duży odsetek nawrotów. Może być ono przydatne przed planowanym zabiegiem, w celu zmniejszenia rozmiarów torbieli, co ułatwia operację.

2. Torbiele średniej wielkości ( $\leq 10 \mathrm{~cm}$ średnicy) są stosunkowo często wycinane z zaoszczędzeniem śledziony i metodą laparoskopową.

3. Torbiele olbrzymie ( $>20 \mathrm{~cm}$ średnicy) są operowane metodą otwartą i często wymagają wycięcia także śledziony (oddzielenie narządu od zmiany jest trudne).

4. Częściowe wycięcie torbieli (fenestracja i marsupializacja) wiąże się ze stosunkowo dużym odsetkiem nawrotów.

5. Częstość nawrotów po częściowym i oszczędzającym śledzionę wycięciu torbieli jest większa po operacjach laparoskopowych (41\%) niż otwartych (2\%).

6. Całkowite wycięcie śledziony z torbielą powinno być wykonywane tylko w przypadkach, gdy nie ma możliwości wykonania operacji oszczędzającej. Takie sytuacje to: kilka torbieli w śledzionie, torbiel olbrzymia i lokalizacja torbieli we wnęce śledziony.

7. Po całkowitym wycięciu śledziony z torbielą można wykonać wszczepienie fragmentu tkanki śledziony do sieci większej, przez co - w części przypadków - udaje się przywrócić częściowo funkcję wyciętego narządu [1, 2, 3, 4, 5].

Pewne zastrzeżenia może budzić wykonanie operacji bez całkowitej pewności, że nie jest to torbiel bąblowcowa. Jak już wspomniano, czas oczekiwania na wynik testu krwi wynosi ok. 7 dni, a ryzyko pęknięcia tak dużej torbieli było znaczne. Dochowano przy tym należytej staranności, prosząc o konsultację doświadczonego specjalistę chorób zakaźnych, który zasugerował leczenie operacyjne bez czekania na wyniki testów na obecność pasożyta. Można było jednak zabezpieczyć się bardziej przed ewentualnością torbieli bąblowcowej przez wykonanie śródoperacyjnego badania parazytologicznego płynu z torbieli. W takim badaniu pasożytniczy charakter torbieli zostaje potwierdzony przez obecność haczyków, protoskoleksów lub fragmentów pęcherza pasożyta. Wówczas do torbieli powinno się podać środek pasożytobójczy.

Przedstawiony w pracy przypadek jest wyjątkowy z powodu znacznych rozmiarów torbieli i jej praktycznie bezobjawowego wzrostu. Wykorzystana technika operacyjna pozwoliła zaoszczędzić narząd, co u młodej osoby ma bardzo istotne znaczenie.

Interesujący jest również inny aspekt opisywanego przypadku. Rozpoznanie zmiany patologicznej nastąpiło w trakcie ćwiczeń z przedmiotu klinicznego, kiedy studenci wykonywali sobie nawzajem badanie USG jamy brzusznej. W tym konkretnym przypadku studentka zauważyła dyskretne zmiany w obrysie brzucha, więc badanie to nie było zupełnie przypadkowe, choć wykonane zostało nieformalnie. Podobny przypadek miał miejsce w tym samym miesiącu, co opisywany, kiedy w trakcie zajęć studenci wykonywali na sobie badanie USG gruczołu tarczowego. U jednej studentki wykryto zupełnie przypadkowo guzek w obrębie miąższu, który wymagał dalszej diagnostyki. Podobne doświadczenia były udziałem starszego autora pracy, który w czasie praktyki wakacyjnej na oddziale wewnętrznym (w latach 70. XX w.) wykonał „z ciekawości” badanie EKG, które - niespodziewanie - wykazało niepełny blok prawej odnogi pęczka Hisa. To akurat nie wymagało leczenia ani zmiany trybu życia, ale oba przypadki z niniejszej pracy (opisywany i wzmiankowany) miały istotny wpływ na dalsze losy obydwu studentek. Stąd refleksja, że wykonywanie sobie nawzajem przez studentów w trakcie ćwiczeń nieinwazyjnych badań (np. USG, EKG, słuchu i wzroku) może przyczynić się do wczesnego wykrycia zmian patologicznych, które przez długi czas mogłyby pozostać nieujawnione.

\section{PIŚMIENNICTWO}

1. Ingle $S B$, Hinge Ingle CR, Patrike S. Epithelial cysts of the spleen: a minireview. World J Gastroenterol 2014;20(38):13899-903. doi: 10.3748/ wjg.v20.i38.13899.

2. Zińczuk J, Wojskowicz P, Kiśluk J, Romaniuk W, Fil D, Kemona A, et al. Torbiel epidermalna śledziony - rzadki przypadek w praktyce klinicznej. Pol Przegl Chir 2014;86:194-7.

3. Cissé M, Konaté I, Ka O, Dieng M, Dia A, Touré CT. Giant splenic pseudocyst, a rare aetiology of abdominal tumor: a case report. Cases J 2010;3(16). doi: 10.1186/1757-1626-3-16.

4. Krasniqi AS, Spahija GS, Hashani SI, Osmani EA, Hoxha SA, Hamza AH, et al. Subtotal resection and omentoplasty of the epidermoid splenic cyst: a case report. Cases J 2009;2:6382 doi: 10.4076/1757-1626-2-6382.

5. Sinha CK, Agrawal M. Nonparasitic splenic cysts in children: Current status. Surgeon 2011;9(1):49-53. 